Dr. sc. Dinka Šago, docentica

Pravnog fakulteta Sveučilišta u Splitu ${ }^{1}$

Andrea Miškić, studentica

Pravnog fakulteta Sveučilišta u Splitu²

\title{
PRIZNAVANJE PRAVA NA POVJERLJIVU PROFESIONALNU KOMUNIKACIJU KORPORATIVNIM PRAVNICIMA
}

\begin{abstract}
UDK: $347.96(497.5)$
Primljeno: 15. 10. 2016.

Pregledni rad

U radu se razmatra pitanje treba li priznati pravo na povjerljivu profesionalnu komunikaciju korporativnim pravnicima. Korporativni pravnici imaju neprocjenjivu ulogu u pružanju pravnih savjeta tvrtkama u predmetima koji zahtijevaju poznavanje poslovanja tvrtke. Takav savjet ne može se zamijeniti savjetom vanjskog pravnika koji nije toliko temeljito upoznat s organizacijom i poslovanjem tvrtke i tržišta na kojima je tvrtka aktivna. Kvaliteta savjeta korporativnog pravnika, njegova učinkovitost i vjerojatnost da će taj savjet biti zatražen može se jamčiti isključivo ako komunikacija do koje je došlo radi dobivanja ili davanja pravnog savjeta bude zaštićena pravom na povjerljivu profesionalnu komunikaciju.
\end{abstract}

Ključne riječi: zastupanje, korporativni pravnici, odvjetnici, neovisnost, profesionalna odgovornost

\section{UVOD}

Korporativni pravnici predstavljuju značajan dio pravničke profesije. U svom radu susreću se s različitim zahtjevima i jedinstvenim izazovima koji proizlaze iz činjenice da pružaju usluge samo jednom klijentu koji je ujedno i njihov poslodavac. U Republici Hrvatskoj na status korporativnih pravnika primjenjuju se opći propisi radnog prava, a organiziranje je svedeno ili na neformalno druženje ili na osnivanje udruga. U RH velik je broj pravnika zaposlen u trgovačkim društvima i drugim pravnim osobama. Od takvih pravnika zahtijeva se izvanredna upućenost u sve pravne odnose u koje društvo stupa, a s obzirom na to i posebna lojalnost i povjerljivost. ${ }^{3}$ Međutim, djelovanje korporativnih pravnika ne iscrpljuje se samo u njihovom djelovanju prema sudovima, državnim tijelima i sl., dakle prema van u Splitu.

1 Dr. sc. Dinka Šago, docentica na Katedri za građansko procesno pravo, Pravni fakultet Sveučilišta

2 Andrea Miškić, studentica Pravnog fakulteta Sveučilišta u Splitu.

3 Markovinović, H., Bilić, A., ,Diversity and Complexity of Company Lawyers' missions: Why Is Intellectual Independence a Mindset? A point of view from Croatia“, u: Company Lawyers Independent 
kada je njihova uloga identična onoj koju imaju odvjetnici kad zastupaju stranke, već je njihovo djelovanje usmjereno i prema unutra, prema samom društvu. Oni su nezamjenjivi u kreiranju pravnih odnosa u koje ulazi društvo i onih unutar društva. Upravo nestručno sročeni ugovori, te nerazriješeni odnosi između organa društva unutar samog društva, često su povod dugotrajnih i skupih sudskih postupaka. U tim segmentima djelovanje korporativnih pravnika prelazi okvire samog društva u kojem rade jer, svakodnevno obavljajući te i slične poslove, brane ne samo dignitet svoje struke nego preventivno djeluju u smislu sprečavanja nezakonitih ponašanja i time nepotrebnih sudskih postupaka te na taj način daju svoj doprinos oživotvorenju načela vladavine prava i rasterećenju pravosuđa. ${ }^{4}$

$\mathrm{S}$ obzirom na to da Udruga pravnika u gospodarstvu kao neformalni oblik organiziranja nije uspjela polučiti veći uspjeh, osim na području obrazovanja, korporativni pravnici su se još 2005. okupili oko Inicijative za osnivanje komore pravnika u gospodarstvu, videći u Komori izlaz iz postojeće situacije. ${ }^{5}$ Smatramo da odvjetnici i pravnici u tvrtkama ne bi trebali biti jedni drugima konkurencija nego se nadopunjavati. Udruga korporativnih pravnika osnovana je 15. svibnja 2007. na tradiciji Udruge pravnika u gospodarstvu koja djeluje od pedesetih godina prošlog stoljeća. ${ }^{6}$ Osnutkom udruge željelo se unijeti pozitivne promjene u karijerni put i status korporativnih pravnika u smislu međusobnog povezivanja i okupljanja svih korporativnih pravnika s položenim pravosudnim ispitom ${ }^{7}$ i njihovim aktivnostima vezanim za promicanja interesa pravne struke u gospodarstvu te strukovnim usavršavanjem. ${ }^{8}$ Udruga korporativnih pravnika od 2007. godine članica je i ECLA-e (European Company Lawyers Association), krovne organizacije europskih udruga korporativnih pravnika. ${ }^{9}$ Temeljni je cilj Udruge pozicionirano i organizirano djelovanje korporativnih pravnika, bilo u okviru zasebne komore ili unutar

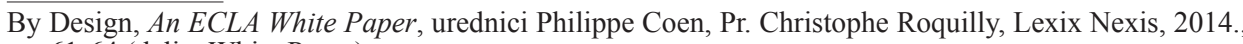
str. 61-64 (dalje: White Paper). 45-51.

${ }^{4}$ Savouré, Jean-Charles, „What Is Expected From The In-house Legal Function?“, White Paper, str.

5 Grčar., I., „Inicijativa 50-ak pravnika zaposlenih u velikim gospodarskim subjektima: Nezadovoljni Hrvatskom odvjetničkom komorom, korporativni pravnici osnovali svoju udrugu“" Lider, br. 93/III, 20. VII. 2007.

6 Slovinić, Jerko, „Osnovana Udruga korporativnih pravnika“, Informator, br. 5560, 20. VI. 2007.

Član Udruge korporativnih pravnika može biti samo pravnik s položenim pravosudnim ispitom, što je i uvjet za upis u imenik odvjetnika.

8 Ideja za osnivanje Udruge nastala je 2005. godine pokretanjem inicijative za osnivanje Hrvatske komore pravnika u gospodarstvu koju su korporativni pravnici pokrenuli zajedno s Hrvatskom gospodarskom komorom, Hrvatskom obrtničkom komorom i Savezom udruga pravnika u gospodarstvu. Formiran je Inicijativni odbor za osnivanje Hrvatske komore pravnika u gospodarstvu i predložene su izmjene Zakona o parničnom postupku. Do danas je poduzeto niz aktivnosti u svrhu zaštite profesionalnog digniteta i slobode rada unutar pravne struke pod ravnopravnim uvjetima. Resorno ministarstvo nije imalo sluha ni za jedan od ovih prijedloga te se i dalje željelo ostvariti ciljeve definirane inicijativom za strukovno organiziranje pravnika u gospodarstvu putem formalne organizacije. U svibnju 2007. godine održana je osnivačka skupština Udruge korporativnih pravnika koja je 01. VI. 2007. godine upisana u registar udruga. Vidi kod Ševerdija, Ajka, „Udruga korporativnih pravnika Hrvatske postala članica European Company Lawyers Association (ECLA)“"// Informator, br. 5606-5607 od 28. XI. i 1. XII. 2007.

9 Ibid. 
Odvjetničke komore. Mišljenja smo da bi svako drugo rješenje bilo problematično sa stajališta ravnopravnosti i ljudskih prava.

O položaju korporativnih pravnika objavljen je White paper Europske asocijacije korporativnih pravnika ECLA, pod nazivom „Korporativni pravnici: nezavisni po funkciji““. ${ }^{10}$ White paper potvrđuje da je intelektualna nezavisnost nužni preduvjet za pravnu struku i relevantno pravno savjetovanje. Pravnici u kompanijama moraju biti efikasni u napadu i u obrani i moraju biti u mogućnosti preuzeti rizike a da ne ugroze integritet i etiku kompanije, što, naravno, zahtijeva davanje pravnih savjeta na nivou potpune intelektualne nezavisnosti. Intelektualna nezavisnost znači slobodu od dogmatskog pristupa, a posebno se podrazumijeva nezavisnost koja nema poveznice $\mathrm{s}$ radnim odnosom ili ugovorom o radu. ECLA-in White paper poziva na daljnji razvoj pravne regulative u zemljama u kojima profesija korporativnih pravnika nije regulirana.

\section{NEOVISNOST}

Korporativni pravnik u svakom je trenutku dužan pružiti profesionalni savjet potpuno neovisno, bez obzira na to utječu li na njega činjenice, interesi ili bilo kakve okolnosti koje nisu bitne za njegov savjet. Korporativni pravnici ne bi se trebali povoditi za uputama ili očekivanjima osoba koje predstavljaju njihove tvrtke u smislu poslodavaca pri pružanju savjeta. Najbolje bi bilo umetnuti odredbu u ugovor o radu svakog korporativnog pravnika, navodeći da je potpuno neovisno pružanje pravnog savjeta u interesu tvrtke, te da ono neće biti razlog otkaza niti bilo kakvih drugih posljedica koje bi bile negativne za napredovanje korporativnog pravnika. ${ }^{11}$ Pravnik mora zadržati svoju neovisnost, te mora imati mogućnost da je zaštiti, kako bi mu se omogućilo da svojim klijentima pruža nepristrane savjete ili da ih zastupa na nepristran način. Korporativni se pravnik mora oslanjati na svoje neovisno, nepristrano profesionalno prosuđivanje kako bi uspješno savjetovao i zastupao svoje klijente. ${ }^{12}$

\section{SUKOB INTERESA}

Korprativni pravnik ne bi se smio dovesti u položaj u kojem se njegovi interesi sukobljavaju s interesima njegovih klijenata ili drugih klijenata, ako to nije na neki drugi način dopušteno zakonom, ili, ako je moguće, ovlaštenjem klijenta. Trebalo bi biti nedvojbeno, u slučaju da se izrazi bilo kakva sumnja u ugovoru o radu, da je tvrtka klijent korporativnog pravnika.

10 White paper se sastoji od priloga korporativnih pravnika iz prakse i znanstvenika koji predstavljaju 20 država sa četiri kontinenta.

11 Mackie, K. J., „Lawyers andlawyers - the development of the in-house lawyer“, Journal of Professional Legal Education, Vol. 5, Issue 1 (June 1987), str. 5-7.

12 Gonzalez Cueto, Tomas, „,The Independence Of Corporate Lawyers“, White Paper, str. 131-136. 
U slučaju grupe tvrtki može se pojaviti pitanje je li klijent kojega se savjetuje grupa u cjelini, matična tvrtka ili podružnica. Općenito, kada nema mogućeg sukoba interesa između članica grupe tvrtki, grupa tvrtki kao takva će se smatrati klijentom. U slučaju postojanja sukoba interesa, korporativnom pravniku koji djeluje kao član grupe čiji je interes suprotan interesu grupe u cjelini, savjetuje se da jasno stavi na znanje koja je njegova uloga kao općeg savjetnika cijele grupe. U slučaju da je klijent članica grupe tvrtki, pravnik bi trebao jasno naglasiti moguće sukobe interesa između članica grupe zajedno s odgovarajućim pravnim položajima, te bi korporativni pravnik trebao jasno objasniti sukobe interesa onima koji donose odluke kako bi se te odluke donosile na dobro odmjerenom temelju. Ako je korporativni pravnik odgovoran izravno upravi, uvijek mora biti svjestan okolnosti kada je odluka koju mora donijeti lokalno poslovno vodstvo suprotna interesu kompanije klijenta, te u tom slučaju korporativni pravnik ima profesionalnu obvezu obavijestiti opći savjet organizacije. Ako izvještavanje općem savjetu nije moguće ili nije učinkovito, ili sam korporativni pravnik predstavlja opći savjet, izvješće se mora predati glavnom direktoru ili predsjedniku uprave.

Korporativni pravnik bi trebao objasniti zaposlenicima tvrtke da on nije i ne može biti njihov osobni pravni savjetnik niti u jednoj situaciji u kojoj se to kosi s njegovom obvezom zastupanja same organizacije.

\section{PRAVNI SAVJET ZA RAZLIKU OD POSLOVNOG SAVJETA}

Većina korporativnih pravnika ima dvostruku ulogu u tvrtki: pravnu i poslovnu, a neki, osim što su pravnici, imaju i funkcije kao što su potpredsjednik ili tajnik. Često pravni savjet obuhvaća barem neke elemente poslovnog savjeta. Stoga je nadzor nad primjenom prava na povjerljivu komunikaciju između pravnika i klijenta daleko veći za korporativne pravnike. Općenito govoreći, komunikacija koja se odvija s korporativnim pravnikom i koja se odnosi na poslovanje ili poslovno savjetovanje nije zaštićena pravom na povjerljivu komunikaciju između pravnika i klijenta. Da bi bila zaštićena pravom na povjerljivu komunikaciju između pravnika i klijenta, komunikacija mora za svoj primarni cilj imati davanje pravnog savjeta. Cesto je isprepletenost pravnog s poslovnim savjetovanjem jednostavno neizbježna. Sudovi odobravaju redigiranje ili isključivanje dijelova dokumenata koji su zaštićeni pravom na povjerljivu komunikaciju ako oni sadrže mješavinu pravnog savjetovanja i poslovnih pitanja. Sudovi smatraju da postoji potreba za povećanim nadzorom kada se radi o primjeni prava na povjerljivu komunikaciju između korporativnog pravnika i klijenta radi mogućnosti sudjelovanja pravnika u komunikaciji s isključivom svrhom omogućavanja primjene prava povjerljivosti i zabrane otkrivanja dokumenta $\mathrm{u}$ istrazi. Zato sudovi često moraju razlikovati pravne od poslovnih aktivnosti pravnika. Činjenica da je pravni savjet prekopiran u dokument ili da je pravnik prisutan na sastanku ne povlači za sobom primjenu povjerljive komunikacije. Obično se u tim okolnostima i ne primjenjuje pravo na povjerljivu komunikaciju, osim ako se može dokazati da do komunikacije ne 
bi došlo da klijent nije imao potrebu za dobivanjem pravnog savjeta. Ako svrha komunikacije nema za primarni cilj dobivanje pravnog savjeta, ta komunikacija neće postati povjerljiva samo zato što su joj dodane primjese pravnog savjetovanja. Nadalje, preporuka pravnika, ili njegovo sudjelovanje u poslovnim aktivnostima, neće bezuvjetno staviti te aktivnosti pod zaštitu povjerljive komunikacije.

\section{PRAVO NA POVJERLJIVU KOMUNIKACIJU}

Pravo na odgovarajući pravni savjet odražava se u principu prava na povjerljivu komunikaciju ${ }^{13}$ koji je poznat pod imenom legal privilege u državama običajnog prava, te pod imenom secret professionnel $\mathrm{u}$ državama građanskog prava. ${ }^{14}$

Oba koncepta uglavnom se temelje na pravu stranke na obranu, a stoga i na ispravno funkcioniranje vladavine prava. U državama običajnog prava dodatni je naglasak stavljen na činjenicu da pravo na povjerljivu komunikaciju (legal privilege) pridonosi vladavini prava. Nadalje, u državama građanskoga prava može se vidjeti razvoj (iako ne u potpunosti) u pravcu stanja Velike Britanije gdje se pravnici bez obzira na to jesu li odvjetnici ili ne, smatraju službenicima suda. Po belgijskom i francuskom pravu, pravnici se sve više smatraju javnim službenicima pravosudnog sustava.

U sustavu običajnog prava koncept prava na povjerljivu komunikaciju razvijen je uglavnom pozivanjem na postupak razotkrivanja u građanskim parnicama. Sve dokazne materijale koje posjeduju obje stranke, bilo da podupiru ili su štetni za slučaj, moraju dostaviti sudu da bi taj sud raspolagao svim relevantnim informacijama.

Postoji razlika između prava na povjerljivu komunikaciju tijekom savjetovanja (advice privilege) i prava na povjerljivu komunikaciju tijekom parničenja (litigation privilege). U oba slučaja dokument će se zaštititi od objelodanjivanja ako je njegova prevladavajuća svrha traženje ili davanje pravnog savjeta.

Secret professionnel smatra se bitnim čimbenikom zanimanja pravnika, jer je neophodno omogućiti stranci da traži pravni savjet s punim povjerenjem kako se podatak koji je iznesen pravniku neće iskoristiti protiv njega. ${ }^{15} \mathrm{U}$ sustavima građanskog prava, secret professionnel ograničava se na one slučajeve kada pravnik poduzima radnje u ulozi pravnika, odnosno kada pruža pravni savjet ili priprema obranu. Ako korporativni pravnik poduzima radnje u ulozi, primjerice, člana uprave

13 Pojam povjerljive komunikacije između pravnika/odvjetnika i klijenta prvi se put pojavljuje $u$ Engleskoj 1577. godine. Pojam je proizašao iz odvjetničke prisege, a u korist klijenta. Temelji se na osnovnom načelu da klijent mora moći s odvjetnikom komunicirati iskreno i bez straha kako bi dobio primjeren savjet. U slučaju kada takva komunikacija ne bi bila povjerljiva, kvaliteta odvjetničkih savjeta bila bi upitna i klijenti bi bili obeshrabreni u potpunom razotkrivanju svih činjenica svojim pravnim zastupnicima zbog straha od samoinkriminacije ili razotkrivanja osjetljivih komercijalnih podataka.

14 Vidi Faull, Jonathan, „In-house lawyers and legal professional privilege: a problem revisited“, The Columbia Journal of European Law, 1998., str. 4.

15 Princip se odražava u kaznenim zakonima zemalja na koje se on odnosi, a kršenje principa sankcionira se po kaznenom zakonu. 
Dr. sc. Dinka Šago i Andrea Miškić: Priznavanje prava na povjerljivu profesionalnu komunikaciju... Zbornik radova Pravnog fakulteta u Splitu, god. 54, 3/2017., str. 645.- 658.

jedne od svojih stranaka, ne može se pozivati na secret professionnel za takav savjet. ${ }^{16} \mathrm{Na}$ taj način, iako nije izričito rečeno kao što je slučaj s običajnim pravom, secret professionnel vezat će se isključivo za one dokumente koji sadrže pravni savjet. Iako je osnova za legal privilege odnosno secret professionnel različita, sveukupni učinak jednog i drugog jest zaštita dokumenata koji sadrže pravni savjet odnosno informaciju koja se odnosi na pripremu obrane od njezinog obznanjivanja vlastima ili drugoj stranci u parnici. ${ }^{17}$

U društvu u kojem postoji vladavina prava, tvrtka mora imati pravo dobiti pravni savjet od pravnika prema vlastitom izboru, a da pri tom ne stvara dokaze protiv sebe, pod uvjetom da takav pravni savjetnik podliježe odgovarajućim propisima etike i discipline. Nema razloga zbog kojeg bi se prema korporativnim pravnicima koji imaju odgovarajuću izobrazbu odnosili na drugačiji način nego prema pravnicima izvan tvrtke u odnosu na ovo pitanje. Priznavanjem prava na povjerljivu komunikaciju unaprijedila bi se usklađenost tvrtki sa zakonom jer bi se smanjila potreba za konzultacijama s odvjetnicima.

Priznavanjem prava na povjerljivu komunikaciju u antitrustovskim postupcima EZ-a ne bi se negativno utjecalo na učinkovitost istraga Komisije. ${ }^{18}$ Niti jedan predmet u kojem je odlučila Komisija do današnjeg dana nije se oslanjao isključivo na dokaze koji su dobiveni iz spisa korporativnih pravnika za uspostavljanje zakonitog postupanja. ${ }^{19}$

Od predmeta AM\&S iz 1982. godine došlo je do značajnog razvoja u opsegu i učinkovitosti istražnih ovlasti za povrede antitrustovskog zakona. Posebno je pri provođenju kartela učinkovitost istraga Komisije narasla primjenom programa popustljivosti i otvaranjem mogućnosti za tvrtke da dobiju potpuni imunitet ili

16 Status i primjena profesionalne tajne različiti su u odnosu na različite pravne sustave, ali osnovni cilj profesionalne tajne u svakoj pravnoj profesiji jest omogućavanje iskrene komunikacije klijenta s odvjetnikom.

ICW podupire jedinstveno načelo profesionalne tajne ili profesionalnu doktrinu povjerljivosti za sve pravnike, bez obzira na to jesu li oni privatni praktičari - odvjetnici ili rade za organizacije/trgovačka društva kao korporativni pravnici. ICW vjeruje da korporativni pravnici podliježu istim standardima i obvezama struke kao i njihovi kolege odvjetnici te klijenti korporativnih pravnika također zaslužuju istu zaštitu. Značajne restrikcije primjene pravila koja osiguravaju primjenu profesionalne tajne moraju biti vezane uz svrhu komunikacije za koju se privilegij profesionalne tajne traži, a ne uz komercijalne ili druge svrhe. ICW podupire stalnu edukaciju svih pravnika i vjeruje da korporativni pravnici trebaju biti svjesni pravila o profesionalnoj tajni u svom pravnom sustavu te educirati svoje organizacije/trgovačka društva o korištenju i primjeni profesionalne tajne. ICW ne odobrava niti jedan oblik razlikovanja u primjeni profesionalne tajne između odvjetnika i korporativnih pravnika istog pravnog sustava. Cilj je stvoriti univerzalni kodeks profesionalne tajne koji bi olakšao međunarodni angažman svih pravnih struka i koji će omogućiti klijentu odabir u angažiranju ili korporativnog pravnika ili vanjskog odvjetnika, a koji odabir će klijentu pružati jednaku zaštitu.

17 ECLA smatra da se nikakva razlika među ovim principima ne bi smjela očitovati u razlikovanju korporativnih pravnika u odnosu na odvjetnike vezano na pravni sustav u kojem rade.

18 Vidi Hughes, J. Trevor, Bellamy, Bojana, „,The Role And Function Of A Data Protection Officer In The European Commission's Proposed General Data Protection Regulation“, White Paper, str. 251-260.

19 Favart, Martin, „The European Commission rejects legal privilege protection for correspondence between outside counsel of opposing companies (Servier, Teva)“", 23 July 2010, e-Competitions Bulletin Legal privilege, Art. $\mathrm{N}^{\circ} 46840$. 
smanjenje globi ako surađuju u istrazi Komisije i ako joj dostave odgovarajuće podatke. Upravo odbijanjem priznavanja prava na povjerljivu komunikaciju korporativnim pravnicima ometaju se unutrašnji postupci koji su potrebni u tvrtkama da bi one donijele odluku o suradnji s Komisijom. ${ }^{20}$

Od svibnja 2004. godine Komisiji se šire istražne ovlasti koje joj stoje na raspolaganju i dobiva pristup podacima nacionalnih vlasti za zaštitu tržišnog natjecanja. Na taj način rezervacija prava na pristup savjetima korporativnih pravnika postaje još nepotrebnija. Istovremeno potreba za pravom na povjerljivu komunikaciju s korporativnim pravnicima raste. To pitanje postaje od iznimne važnosti u pogledu neminovnih modernizirajući reformi i zahtjeva za samoprocjenom usklađenosti za zakonima za zaštitu tržišnog natjecanja. Priznavanje uloge korporativnih pravnika u usklađivanju smanjilo bi teret provođenja zakona Komisiji, nacionalnim vlastima i sudovima.

Zaštita prava na povjerljivu komunikaciju korporativnim pravnicima ne bi bila apsolutna. Primjenjivala bi se sljedeća ograničenja protiv kršenja i zlouporabe, tako da se očuva učinkovitost istražnih ovlasti Komisije: 1 . Pravo na povjerljivu komunikaciju odobravalo bi se samo za komunikaciju s korporativnim pravnikom kojeg obvezuju profesionalne etičke norme koje se učinkovito provode i koje su utemeljile i provode ih profesionalne udruge čiji je taj pravnik član u općem interesu; 2. Pravo na povjerljivu komunikaciju pokrivalo bi isključivo komunikaciju koja sadrži traženje pravnog savjeta od korporativnog pravnika koji izvršava dužnosti korporativnog pravnika, a ne onoga koji izvršava dužnosti koje spadaju u upravu ili vođenje poslovanja; 3 . Pravo na povjerljivu komunikaciju gubilo bi se u onim slučajevima u kojima je korporativni pravnik uključen u nezakonito ponašanje ili u kojem tvrtka uništava dokaze. ${ }^{21}$

\subsection{Povjerljivost - profesionalna tajna}

Korporativni pravnik mora se u svakom trenutku pridržavati načela povjerljivosti i mora mu se omogućiti zaštita povjerljivosti u svim pitanjima o njegovim sadašnjim ili bivšim klijentima, ako zakon ne traži ili ne dopušta suprotno, ili ako suprotno nije dopušteno klijentovim ovlaštenjem. Budući da je klijent korporativnog pravnika tvrtka (ili grupa tvrtki), obveza povjerljivosti odnosi se na zaštitu interesa tvrtke i to bi trebala biti smjernica korporativnim pravnicima pri procjeni opsega povjerljivosti i izvan i unutar tvrtke. Posebno kada govorimo o pravu na profesionalnu povjerljivu komunikaciju koja se primjenjuje na savjet što ga korporativni pravnik pruža svojoj

20 Povreda ljudskih prava kroz osporavanje prava na povjerljivu komunikaciju, govor Jettiea Van Caenegema, potpredsjednika ECLA-e u Međunarodnoj odvjetničkoj komori (IBA) u Parizu, 21. veljače 2002. godine. http:// www.udruga-korporativnihpravnika.hr/dld/POVREDA\%20LJUDSKIH $\% 20$ PRAVA \%20KROZ\%20OSPORAVANJE\%20PRAVA\%20NA\%20POVJERLJIVU\%20 KOMUNIKACIJU.pdf

${ }^{21}$ Rakesh K. Prusti, „Why Company Lawyers Are The Guardians Of Corporate Integrity?“, White Paper, str. 275-282. 
tvrtki kao klijentu, korporativni bi pravnik trebao pažljivo razmotriti osnovu potrebe za saznanjima u svojoj komunikaciji.

U slučaju da je korporativni pravnik član uprave, korporativni pravnik ne bi trebao nuditi pravne savjete upravi, osim ako izričito ne obavijesti upravu da neće sudjelovati u postupku donošenja odluke. Treba imati na umu da je ovo izuzeće moguće isključivo u slučajevima kada primjenjivi zakon omogućava članovima uprave da se izuzmu uz pravni učinak jer se ne smatraju odgovornima za odluku.

Korporativni pravnici nemaju isti obim prava na povjerljivu komunikaciju između pravnika i klijenta kao vanjski pravnici. Problem je u tome što sudovi ne smatraju komunikaciju povjerljivom samo zato što je u njoj sudjelovala osoba koja je pravnik. Komunikacija je povjerljiva isključivo ako je primarni cilj te komunikacije ostvarivanje svrhe povjerljivosti između pravnika i klijenta. Drugim riječima, komunikacija se mora odvijati s ciljem traženja, dobivanja ili pružanja pravnog savjeta. Pravo na povjerljivu komunikaciju između pravnika i klijenta konkretno štiti komunikaciju između pravnika i klijenta kada se ta komunikacija: 1) odvija s ciljem traženja ili pružanja pravnog savjeta za razliku od poslovnog savjeta, 2) ako je ona povjerljiva u trenutku kada se odvija, 3) te ako je klijent čuva kao poslovnu tajnu. ${ }^{22}$

\subsection{Tko je klijent korporativnog pravnika?}

Opseg prava na povjerljivu komunikaciju između pravnika i klijenta jedinstven je kada pravnik predstavlja trgovačko društvo. Opće je poznato da svi zaposlenici tvrtke nisu „klijenti“. Sudovi primjenjuju dvije teorije pri odlučivanju s kojim zaposlenicima trgovačkog društva korporativni pravnik može komunicirati u kontekstu prava na povjerljivu komunikaciju.

Jedna je teorija „ispitivanje uprave“ po kojoj se isključivo razgovor između korporativnog pravnika te osoba koje obnašaju izvršne funkcije uprave i direktora smatra komunikacijom koja udovoljava kriterijima zaštite. Često se „uprava“ tvrtke sastoji od vrlo ograničenog broja zaposlenika te tvrtke. ${ }^{23}$

U predmetu Upjohn, ${ }^{24}$ Vrhovni je sud proširio ispitivanje uprave i uključio istraživanje biti komunikacije. Po toj teoriji se svi zaposlenici koji imaju važne informacije za predmet spora smatraju „klijentima“, bez obzira na njihov položaj u tvrtki. Tako da svaki zaposlenik tvrtke može razgovarati s korporativnim pravnikom

22 Usporedi Boykin, James H., „Legale Privilege - the Debate, report on the debate“, The Annual Conference of the International Bar Association in Prague, str. 19-21.

23 Paschos, Thomas, Očuvanje prava korporativnih pravnika na povjerljivu komunikaciju između pravnika $i$ klijenta, http://www.udruga-korporativnih-pravnika.hr/dld/legal\%20privilege\%20in\%20usa. pdf

24 Vidi odluke Suda Europske unije donesene u Predmetu Upjohn, Case C-120/97, Upjohn Ltd v The Licensing Authority established by the Medicines Act 1968 and Others, 1999., European Court Reports I - 223. te u Predmetu Land Rheinland-Pfalz/Alcan Deutschland, Case C-24/95, Land Rheinland-Pfalz v Alcan Deutschland GmbH, 1997., European Court Reports I - 1591. 
uz primjenu prava na povjerljivu komunikaciju. Međutim, komunikacija nije uvijek zaštićena pravom povjerljivosti. Do problema dolazi zato što mnogo zaposlenika trgovačkih društava često ima dojam da s korporativnim pravnikom mogu raspravljati o bilo kakvom pravnom problemu tvrtke i da će ta komunikacija biti povjerljiva. Nema svaki zaposlenik trgovačkog društva pravo na povjerljivu komunikaciju o svakom pravnom pitanju. Ako komunikacija ne spada u opseg odgovornosti tog zaposlenika, ona nije zaštićena pravom na povjerljivost. Također, neki zaposlenici mogu biti izvan djelokruga prava na povjerljivu komunikaciju, bez obzira na to o kakvim se pravnim pitanjima radilo. Do problema dolazi kada su ti zaposlenici prisutni na sastancima na kojima korporativni pravnik daje pravne savjete. ${ }^{25}$

\subsection{Priznavanje prava na povjerljivu komunikaciju u sudskim odlukama}

Nizozemski Vrhovni sud priznao je pravo na povjerljivu informaciju za korporativne pravnike u predmetu koji je vodio Freerk Vermeulen za NautaDutilh vs Dutch multi utility company Delta. ${ }^{26} \mathrm{U}$ ovom je predmetu sud 15. III. 2013. donio odluku u kojoj je priznao da korporativni pravnici imaju pravo na tzv. legal privilege odnosno da je komunikacija između njih i uprave društva povjerljive prirode. Sve je započelo s predmetom AKZO Nobel u kojem je Europski sud pravde odbio priznati povjerljivost informacija za nizozemske korporativne pravnike iz razloga ovisnosti. ${ }^{27}$ Po odluci Europskog suda pravde, radni odnos zaposlene pravnike čini nedovoljno neovisnima da bi se priznalo pravo na povjerljivu komunikaciju između njih i uprave društava. Upravo zbog toga je postojao strah kod korporativnih pravnika hoće li sud slijediti primjer Europskog suda pravde odnosno kakvu će odluku donijeti Vrhovni sud u slučajevima kad se ne radi o pravu tržišnog natjecanja. Vrhovni je sud odlučio priznati pravo na povjerljivost u komunikaciji kad se radi o korporativnim pravnicima koji su članovi komore, što je u Nizozemskoj slučaj da korporativni pravnik s položenim pravosudnim ispitom može biti član posebnog razreda odvjetničke komore, te donio odluku da takvi korporativni pravnici imaju pravo na legal privilege. ${ }^{28}$ Unatoč predmetu Akzo u kojem je korporativnim pravnicima uskraćeno pravo na povjerljivost komunikacije pred Europskom komisijom, belgijske vlasti nadležne za tržišno nadmetanje ne smiju kršiti pravo korporativnih pravnika na povjerljivu komunikaciju sa svojim klijentima u Belgiji. ${ }^{29}$

25 Vidi Carr, Josephine, „Should In-House Lawyers have Lawyer/client Privilege?“, International Business Lawyer, December, 1996.

$26 \mathrm{https}: / / w w w . l e x g o \cdot b e /$ en/papers/divers/divers/dutch-supreme-court-confirms-legal-privilege-forin-house-attorneys, $79713 . \mathrm{html}$

27 Više Feugère, William, ,The Independence Of In-House Counsels In France: Bridging The Gap With Lawyers“, White Paper, str. 123-130.

28 Nizozemska odvjetnička komora i njezin razred korporativnih pravnika podržava pravo korporativnih pravnika na legal privilege. Vrhovni sud podržava pravo na povjerljivu informaciju za korporativne pravnike dok god djeluju u interesu svog poslodavca, http://www.udruga-korporativnihpravnika.hr/

29 Kooy, Han, „Independence Of The Company Lawyer: The Netherlands Point Of View“, White Paper, str. 229-231. 
Naime, Belgija ima jedinstveni model prema kojem se korporativni pravnici mogu učlaniti u IJE - Institut des Juristes d'Entreprise, Belgijsku udrugu korporativnih pravnika, i koristiti pravo na povjerljivu komunikaciju sa svojim klijentima. Nakon presude donesene 5. ožujka 2013. godine, Briselski prizivni sud priznao je da su dokumenti što su ih predali korporativni pravnici zaštićeni pravom na povjerljivu komunikaciju u istragama koje se vode prema Belgijskom zakonu o tržišnom natjecanju. Ova se presuda udaljava od sudske prakse europskih sudova i protivi se praksi donošenja odluka određenog broja nacionalnih tijela nadležnih za tržišno natjecanje.

U postupku pred Europskim sudom pravde, a vezanom na zaštitu tržišnog natjecanja, donesena je 14. IX. 2010. odluka u predmetu AKZO Nobel. Europski sud pravde potvrdio je odluku suda opće nadležnosti da u postupcima zaštite tržišnog natjecanja komunikacija korporativnih pravnika s društvom u kojem rade nije zaštićena kao povjerljiva. U obrazloženju koje je Sud pri tome dao polazi se od činjenice da radni odnos predstavlja ovisnost o poslodavcu. ${ }^{30} \mathrm{~S}$ druge strane, kad odvjetnik zastupa pravnu osobu, on je nezavisan i ta mu nezavisnost daje pravo na povlaštenost prilikom davanja pravnih mišljenja. Pri tome možemo postaviti pitanje po čemu je onda radni odnos korporativnog pravnika različit od ugovornog odnosa odvjetnika. Ni po čemu, pogotovo ako se uzmu u obzir odvjetnička društva u kojima su pravnici - odvjetnici zaposlenici odvjetničkog društva.

Europski sud pravde donio je odluku u slučaju AKZO Nobel vodeći se preporukom javne tužiteljice Kokott. Sud je potvrdio odluku suda opće nadležnosti koji je uskratio pravo na povjerljivu komunikaciju (legal privilege) u predmetima prava na zaštitu tržišnog natjecanja pravnicima koji su zaposleni u tvrtkama i koji imaju samo jednog poslodavca. ${ }^{31}$ Europski sud pravde drži da korporativni pravnici koji su u radnom odnosu ne mogu djelovati neovisno i stoga se ne mogu tretirati kao vanjski savjetnici. ${ }^{32}$ Predsjednik Europske udruge korporativnih pravnika (ECLA), Han Kooy je rekao: Posljedica je ove odluke zadržavanje različitog položaja korporativnih pravnika u odnosu na položaj pravnika koji rade u odvjetničkim uredima. Ovom se odlukom ne pomaže tvrtkama budući da se moraju oslanjati na skupe usluge odvjetničkih ureda kako bi komunicirale sa svojom upravom o predmetima europskog prava zaštite tržišnog natjecanja. Sud opće nadležnosti je 2008. godine donio odluku da agenti Europske komisije nemaju pravo na pristup tim dokumentima bez dopuštenja suda opće nadležnosti. U toj odluci Europski sud pravde izričito navodi da korporativni pravnici ne bi trebali imati pravo na

30 Wesseling, Rein, Miranda de Savorgnani, ,The EU Court of Justice confirms that communications with an in-house lawyer are not legally privileged (AKZO)“, 14 September 2010, e-Competitions Bulletin Legal privilege, Art. N 39501.

31 Favart, Martin,"The ECJ Advocate General Kokott advises against the extension of legal professional privilege to in-house lawyers (Akzo Nobel)“", 29 April 2010, e-Competitions Bulletin Legal privilege, Art. $\mathrm{N}^{\circ} 46668$.

32 Jean-François Bellis, „Legal professional privilege: An overview of EU and national case law“, 26 October 2011, e-Competitions Bulletin Legal privilege, Art. Nº 39467 
povjerljivu komunikaciju (legal privilege) zato što su u radnom odnosu. ${ }^{33} \check{C}$ ekali smo preko 30 godina da se preinači odluka iz 1982. godine, a sada smo se vratili na početak. Stoga smo izrazito nezadovoljni ishodom, rekao je Han Kooy iz Den Haguea. ${ }^{34} 35$

\section{KORPORATIVNI PRAVNIK KAO ZASTUPNIK PRED EUROPSKIM SUDOM PRAVDE}

Trenutna praksa Suda pravde jest ta da korporativni pravnici ne mogu zastupati svoje tvrtke na Sudu, niti se obraćati Sudu u njihovo ime. U članku 19. Statuta Suda pravde navodi se da stranke mora zastupati pravnik. Sud tumači čl. 19. tako da pravnik mora biti neovisan. Sud tumači neovisnost kao nepostojanje radnog odnosa između pravnika i njegova klijenta (EREF protiv Komisije, stavak 53). Sud ne definira načelo neovisnosti pravnika samo pozitivno, odnosno pozivanjem na profesionalne etičke obveze, već i negativno, odnosno nepostojanjem radnog odnosa (Akzo Nobel Chemicals i Akcros Chemicals protiv Komisije, st. 45.). ${ }^{36}$ Trebalo bi razmotriti mogućnost donošenja izmjena i dopuna čl. 19. Statuta Suda pravde kako bi se omogućilo strankama da ih mogu zastupati pravnici koje su one odabrale, uključujući i korporativne pravnike. Vjerujemo da bi se takvom izmjenom i dopunom čl. 19. uskladilo zastupanje pred Sudom pravde sa slobodom poslovanja definiranom u čl. 16. Povelje o temeljnim pravima Europske zajednice. Smatramo da bi se davanje jednakih prava i pred Sudom pravde (korporativnim pravnicima koji uživaju to pravo u svom vlastitom zakonodavstvu) moglo postići bez narušavanja neovisnosti uloge pravnika u europskom pravnom poretku. U čl. 16. Povelje priznaje se pravo vođenja poslovanja u skladu sa „Zakonom zajednice i nacionalnim zakonima i praksom“. Međutim, nacionalni zakoni i praksa u nekoj državi članici omogućuju tvrtkama zastupanje njihovih korporativnih pravnika u sporovima koji se vode pred nacionalnim sudovima. Sud je prihvatio da sloboda iz čl. 16. „obuhvaća, među ostalim, pravo bilo kojeg poslovnog subjekta na slobodno korištenje, unutar granica odgovornosti za svoje vlastite postupke, ekonomskih,

33 Favart, Martin, „The European Court of Justice dismisses applications to intervene in an appeal against a Commission decision not to grant legal privilege to two sets of documents copied by the Commission in the course of a dawn raid (Akzo Nobel)“, 9 September 2009, e-Competitions Bulletin Legal privilege, Art. $\mathrm{N}^{\circ} 46373$.

34 Kooy, Han, op. cit. (bilj. 27), str. 229-231.

35 AKZO Nobel se žalio na odluku agenata Komisije da uzmu dokumente iz AKZO-ovih ureda blizu Manchestera. AKZO-u se u slučaju pridružilo osam umješača. Nizozemska odvjetnička komora (the Netherlands Bas Association - Nederlandse Orde van Advocaten), Međunarodna odvjetnička komora (the International Bar Association), Vijeće odvjetničkih komora u Europskoj uniji (the Council of Bars in the EU), Međunarodna odvjetnička komora (the International Bar Association), Američka udruga korporativnih pravnika (the American Corporate Counsel Association), te vlade Ujedinjene Kraljevine, Irske i Nizozemske.

36 Depoortere, Frederic, Venit, James S., ,, The European Court of Justice holds that in-house lawyers are not protected by legal professional privilege in antitrust investigations (Akzo)“, 14 October 2010, e-Competitions Bulletin Legal privilege, Art. N 46325. 
tehničkih i financijskih izvora koji mu stoje na raspolaganju“. U mnogim slučajevima tvrtke mogu dati prednost korištenju vlastitih korporativnih pravnika jer je to daleko učinkovitije s financijske strane, ali i zbog boljeg poznavanja poslovanja tvrtke u praksi, posebno u određenim postupcima pred Sudom pravde, kao što je to slučaj u postupku ispitivanja prije suđenja kada će korporativni pravnik biti u daleko boljem položaju kada bude odgovarao na pitanja koja sud može postaviti strankama tijekom saslušanja od bilo kojeg vanjskog pravnika. Mišljenja smo da ako države članica EU dopuštaju da korporativni pravnici obavljaju svoja profesionalna zaduženja pred sudovima, Sud pravde bi to isto tako trebao dopustiti. To je osobito važno za ispitni postupak prije suđenja, u kojem korporativni pravnici zastupaju svoje tvrtke pred nacionalnim sudovima.

\section{ZAKLJUČAK}

Zapošljavanjem pravnika u gospodarstvu, trgovačka društva iskazuju potrebu da osobu od svog povjerenja imaju u društvu. Neosporno je da odvjetnik ne može u gospodarstvu zamijeniti korporativnog pravnika. Sve pravne osobe imaju neposredne koristi, kako iz preventivnog djelovanja korporativnog pravnika, tako i iz njihova angažmana u sudskim postupcima. ${ }^{37}$ Mišljenja smo da bi u Republici Hrvatskoj trebalo osnovati komoru korporativnih pravnika kakvu imaju odvjetnici i javni bilježnici. Naime, u većini europskih država zakonskim je odredbama riješeno da korporativni pravnici mogu biti članovi posebne komore, a u nekim slučajevima mogu osnivati i jedinstvene komore zajedno s odvjetnicima. Istina je da odvjetnički uredi mogu djelomično preuzeti poslove korporativnih pravnika, ali uvijek postoje segmenti poslovanja u kojima je nužno imati kućnog odvjetnika (in house lawyer) jer svaka gospodarska grana ima svoje specifičnosti i nemoguće je da odvjetnici mogu istom kvalitetom pokrivati telekomunikacijski i energetski sektor, radno pravo ili tržišno natjecanje. Sve to tim više što se pravo sastoji od niza različitih grana u kojima su nužni svakodnevno praćenje propisa, paralelno znanje staroga i novog zakonodavstva i harmonizacija s Europskom unijom.

Smatram da budućnost leži u suradnji pravnika, odvjetnika i svih ostalih pripadnika pravne struke. Nažalost, Državna škola za pravosudne dužnosnike, ustanovljena 2009., namijenjena je isključivo sucima i državnim odvjetnicima pa narušava odnose i smanjuje mobilnost unutar pravne struke. Stoga smatramo da bi pravna struka kao cjelina trebala biti predmet interesa Ministarstva pravosuđa. ${ }^{38}$

Smatramo nužnim zakonsko reguliranje položaja korporativnih pravnika u funkciji unapređenja njihova rada, a time i cijele pravne struke, uspostavljanjem odgovarajućeg oblika njihova profesionalnog organiziranja. Tako bi se posebnim

37 Vidi Giunio, A. Miljenko, „Parnična sposobnost i pravosudna učinkovitost“, Zbornik radova Pravnog fakulteta u Splitu, god. 38, 2001., str. 161-166.

38 Tako Šago, Dinka, ,Osobe u radnom odnosu sa strankom kao njeni punomoćnici u parničnom postupku“, Pravo u gospodarstvu, br. 3, 2013., str. 669-671. 
Dr. sc. Dinka Šago i Andrea Miškić: Priznavanje prava na povjerljivu profesionalnu komunikaciju... Zbornik radova Pravnog fakulteta u Splitu, god. 54, 3/2017., str. 645.- 658.

zakonom mogla regulirati nova, treća pravnička komora, uz odvjetničku i javnobilježničku, Hrvatska komora korporativnih pravnika. ${ }^{39}$ Druga mogućnost bila bi izmijeniti i dopuniti Zakon o odvjetništvu ${ }^{40} \mathrm{u}$ smislu ustrojavanja posebnog razreda korporativnih pravnika unutar HOK-a. Treća bi mogućnost bila temeljem zakona ukinuti postojeće komore pravnih profesija i organizirati novu jedinstvenu komoru $\mathrm{s}$ više razreda (razred odvjetnika, razred javnih bilježnika, razred korporativnih pravnika). ${ }^{41}$

U društvu u kojem postoji vladavina prava, tvrtka mora imati pravo dobiti pravni savjet od pravnika prema vlastitom izboru, a da pri tom ne stvara dokaze protiv sebe, pod uvjetom da takav pravni savjetnik podliježe odgovarajućim propisima etike i disciplinske odgovornosti. Nema razloga zbog kojeg bi se prema korporativnim pravnicima koji imaju odgovarajuću izobrazbu odnosili na drugačiji način nego prema pravnicima izvan tvrtke u odnosu na ovo pitanje. Priznavanjem prava na povjerljivu komunikaciju unaprijedila bi se usklađenost tvrtki sa zakonom jer bi se smanjila potreba za konzultacijama s odvjetnicima.

Korporativni pravnik uvijek bi morao biti svjestan da interes tvrtke nije isključivo usklađenost sa zakonom, već i s etičkim načelima i opravdanim očekivanjima društva, što je iznad zakona i čije nepoštovanje može tvrtku stajati njezine reputacije. U tom kontekstu,e od korporativnog se pravnika očekuje da njegov savjet bude u interesu tvrtke, a to je interes svih važnih i legitimnih zainteresiranih stranaka te tvrtke u svakom slučaju, a ne samo jednog ili više zainteresiranih stranaka (npr. dioničara).

Situacija europskih korporativnih pravnika različito se razvija od države do države. U nekim regijama postoji dinamična zakonodavna aktivnost u cilju poboljšavanja njihova položaja. Primjerice u Njemačkoj, vodi se debata o mirovinskom sustavu za dvije kategorije pravnika, korporativne pravnike i odvjetnike. ${ }^{42} U$ istočnoeuropskim zemljama situacija se razvija na posebno pozitivan način, s obzirom na to da postoji

39 Havliček., M., ,Inicijativom do Hrvatske komore pravnika u gospodarstvu: Pravnik u gospodarstvu - blagodat za tvrtku“"// Informator, br. 5395, 19. XI. 2005.

40 Zakon o odvjetništvu, Narodne novine, br. 09/94, 117/08, 50/09, 75/09, 18/11.

41 Više Šago, Dinka, op. cit. (bilj. 36), str. 669-671.

42 https://anwaltverein.de/de/ Za razliku od odvjetnika koji doprinos za mirovinsko osiguranje plaćaju u zaseban mirovinski fond (pension fund of the advocacy), korporativni su pravnici u Njemačkoj do prosinca 2015. uplaćivali doprinos za mirovinsko osiguranje u državni fond (state pension). Godine 2015. donesen je zakon s ciljem uređenja predmetne problematike, čime je uvedena mogućnost izuzimanja korporativnih pravnika od obveze plaćanja doprinosa za mirovinsko osiguranje državnom mirovinskom fondu i plaćanje doprinosa zasebnom mirovinskom fondu, kao što plaćaju odvjetnici. No, ono što posebno ističemo jest činjenica da je navedenim zakonom prvi put u Njemačkoj uređen položaj korporativnih pravnika kao dijela pravne profesije, kao i njihova mogućnost učlanjenja u komoru kao korporativnih pravnika. Pravna je struka u Njemačkoj jedinstvena pa su tako odvjetnici i korporativni pravnici dio iste struke (advocates/lawyers), a u poslu korporativni pravnici nose naziv lawyer (company lawyer) odnosno Rechtsanwalt (Syndikusrechtsanwalt). Svi su pravnici članovi iste komore. Pravnik može biti član komore kao: 1) odvjetnik, 2) korporativni pravnik ili 3) oboje. Svaka opcija zahtijeva zasebnu prijavu komori. Prijava korporativnog pravnika u komoru usko je vezana uz činjenicu zaposlenja te pri svakoj promjeni zaposlenja (pa čak i unutar istog poslodavca) članstvo prestaje i mora se predati nova prijava za članstvo u komori. Prilikom prijave u komoru, strogo se ispituje obavlja li korporativni pravnik zaista pravne poslove za poslodavca te je li istom zajamčena neovisnost - to se dokazuje ispravom poslodavca (izjava o 
prihvaćanje mogućnosti da korporativni pravnici daju pravne savjete koji bi vrijedili i na sudovima, primjerice u Estoniji i Latviji. U Francuskoj je otvoren dijalog, ali je pozicija Komore zaista jaka, ${ }^{43}$ kao i u Italiji u kojoj skoro da i ne postoji zanimanje javnosti za položaj korporativnih pravnika. ${ }^{44} \mathrm{U}$ Španjolskoj su korporativni pravnici i odvjetnici članovi iste Komore. ${ }^{45}$ Ipak, posljednjih godina u gotovo cijeloj Europi postaje sve učestalije da korporativni pravnici odlaze raditi u odvjetničke urede, a da mlađi, ali i zreliji odvjetnici, započinju karijeru korporativnih pravnika. Dakle, ako se ta dva zanimanja mogu međusobno zamijeniti, postavlja se pitanje zašto bi podlijegala drugačijim pravilima. ${ }^{46}$

\section{ACKNOWLEDGEMENT OF LEGAL PROFESSIONAL PRIVILEGE FOR COMPANY LAWYERS}

Company lawyers are one of the most numerous legal professions in Croatia whose members are perceived as highly professional, often with very profound legal knowledge in many different fields of law. Wide legal knowledge that company lawyers frequently have is a result of a diversity of tasks they are confronted with throughout their professional life and great understanding of the business processes taking place in the companies they work for.

This paper briefly deals with the main challenges which are placed before company lawyers in Croatia with the accent on diversity and complexity of their tasks, as well as with the issue of their intellectual independence.

Keywords: representation, company lawyers, lawyers, independence, professional duty

„dodjeli” neovisnosti) ili ugovorom o radu u kojem je sadržana odredba o „dodjeli” neovisnosti. Također, detaljno se proučava opis poslova koje korporativni pravnik obavlja i ugovor o radu istog.

Korporativni pravnici u Njemačkoj donekle imaju legal privilege, osim u kaznenim postupcima gdje mogu biti pozvani kao svjedoci, uredi im mogu biti predmet pretrage, a dokumentacija predmet zapljene. U odnosu na pravo zastupanja, poslodavce mogu zastupati u ograničenom broju postupaka, onima u kojima je VPS do 5.000,00 eura i nije propisano obvezno zastupanje od strane odvjetnika. Također, korporativni pravnici, za razliku od odvjetnika, ne moraju imati obvezno osiguranje od profesionalne odgovornosti.

43 Feugère, William, „The Independence Of In-House Counsels In France: Bridging The Gap With Lawyers", White Paper, str. 123-130.

${ }^{44}$ AIGI, talijanska udruga korporativnih pravnika - nacionalna organizacija korporativnih pravnika u Italiji, osnovana je 1976. godine od strane vodećih pravnika iz velikih kompanija. Danas ima preko 1000 članova s vrlo širokim spektrom aktivnosti od kojih je važan segment zaštita profesije i obrazovanje. Godine 1986. pridružili su se ECLA-i i od onda imaju važnu ulogu u njezinu radu i promociji pravnika na europskom nivou. U prosincu 2013., nakon duljeg razdoblja provjere, talijansko ministarstvo pravosuđa službeno je uvrstilo AIGI na listu vodećih asocijacija za neregulirane profesije na nacionalnom nivou predstavnik na nacionalnom nivou, a vezano na implementaciju Direktiva 2005/36/UE.

45 Cremades, Juan Antonio, „The Independence Of Company Lawyers As An Ethical Duty: The Case Of Spain“, White Paper, str. 155-158.

46 Vidi Slovinić, Jerko, „Usporedni prikaz organiziranja korporativnih pravnika“, Informator, br. 5633,2008 . 